\title{
URBAN GREEN SPACE MANAGEMENT AS A SUPPORT FOR THE CLIMATIC FUNCTION OF VEGETATION IN URBAN ENVIRONMENT (CASE STUDY - NITRA)
}

\author{
Katarína Veselovská, Gabriel Bugár
}

\begin{abstract}
Regarding to global trend of increasing maximum of air temperature and extreme weather, concerned groups in cities focus on effective adaptation on these significant changes. One of the possibilities of how to solve this situation is the support of green infrastructure in local level. This study is focusing on evaluation of experiment with different type of management of green spaces as the tool for potential elimination of overheating of active surface in summer. The active management contributes to favorable thermal balance during the day. Our research shows the daily amplitude of overheating of active surface. Cooling effect and thermoregulation occur in the earlier hours, in comparing to study areas with unsuitable management. After the evaluation of analysis in the locality with study areas we can state, that the optimal management in summer months is the management with mowing in the height of $15-20 \mathrm{~cm}$ without retained of grass biomass.
\end{abstract}

Keywords: green infrastructure, microclimate, daily amplitude, thermal images

\section{Introduction}

The active surface is the main climatic factor in urban environment. The significant attribute for definition of microclimate is the ground layer of atmosphere. Vertical gradients of wind, temperature and other meteorologic elements achieve maximum values. According to Oke (2006) the ground layer of atmosphere includes air's layer closed by anthropogenic surface, from terestrial surface to average hight of buildings. Preferable data source about spatial variability of active surface temperature are satellite images (Vooght, Oke, 2003). Vegetation plays significant role in the formation of microclimate and thermal comfort. According to Wardoyo (2011) the urban environment specific to hard surface is typical urban geometry, vegetated areas and variability of surface materials. Different thermal attributes of active surfaces with different material lead to increasing of heat absorption in the time of possitive energy balance (Středová et al., 2011). Urban green spaces are under a permanent pressure and the potential of green spaces is not always realized. Since current management practices are sometimes sub-optimal, it is of strategic importance to create an analytical and taxonomic framework for mapping out the importance of green 
space in cities (Patassini, 2017). Urban green spaces are considered as one type of nature-based solutions that use urban ecosystem services to provide mitigation and adaptation actions and solutions to climate change and urbanisation related challenges (Kabisch et al., 2017). The elements of the green infrastructure in the urban space provide a high variety of ecosystem services. A clarification of the benefits urban residents gain from urban green spaces as well as control of urban green quality at the city level are necessary to derive and pinpoint urban planning and nature conservation strategies in this context (Grunewald et al., 2017). Common management practices - such as maintenance of turf grass lawns, tree and shrub pruning, pesticide and herbicide applications, and introduction of non-native plant species - threaten the biodiversity of cities. Despite common misconceptions that cities are species poor, new evidence suggests otherwise and that UGS are vital for supporting urban biodiversity and adaptation of cities on climate change (Aronson et al., 2017). According to Koc et al. (2018) experimental studies involve the manipulation of green features by researchers, enabling measurements under relatively controlled conditions. The effect of trees and grass on thermal comfort was also investigated through experimental sites, though these studies were very few. Measurements collected on an experimental basis also served to validate predictive models and to parameterise computer simulations. Available studies about management of green areas focus on evaluation of phyto-diversity grass-herbal comunities (Belíková, Mackovová, Kočík, 2013), managment model of mesophilic meadows (Ružičková, Škodová, Janák, 2009), and model measure for arid de-alpin grass-herbal comunities (Janišová, Janák, 2009). Plantureux, Peeters, McCracken, (2005) in their study focused on impact of managment of intensive grassland on biodiversity. The aim of our study is the evaluation of experiment with different type of management of green spaces as the tool for potential elimination of overheating of active surface in summer.

\section{Materials and methods}

For evaluation of impact of managment of green spaces on accumulation of solar radiation and the surface temperature were established model areas (1.5 x 3 $\mathrm{m})$. Model areas were exposed to direct solar radiation in the time of possitive energy bilancy. For realization of this experiment it was necessery to select model areas in locality with absention of tree's vegetation because of elimination the overshadow, with dominant representation Poа аппиа (l.), outside the normal avaibility of inhabitants. Model areas were established in summer season 2016 in the areal of Cultural Center Hidepark Nitra (Map 1). In the selected study areas there were implemented active managment interventions: Study area 1 - complete mowing with uncovering of soil; Study area 2 - complete mowing with uncovering of soil and retained of grass biomass; Study area 3 - mowing in the 
height of $10 \mathrm{~cm}$; Study area $4-$ mowing in the height of $10 \mathrm{~cm}$ and retained of grass biomass; Study area 5 - mowing in the height of $15-20 \mathrm{~cm}$.

In the study areas there were implemented measurments of climatic factors using by Anemometer TSI Veloci Calc and Infrared thermometer:

surface temperature $\left[{ }^{\circ} \mathrm{C}\right]$; relative air humidity and air temperature $\left[{ }^{\circ} \mathrm{C}, \%\right]-$ in height of $20 \mathrm{~cm}$ over the surface of study area; relative air humidity and air temperature $\left[{ }^{\circ} \mathrm{C}, \%\right]-$ in height of $2 \mathrm{~m}$ over the surface of locality with study area. The legwork was accomplished in summer season 2016, in the 5 selected days with optimal conditions for research of microclimate in the urban environment in time of possitive energy bilance (anticyclone type of weather with radiation mode, without rainfall, with velocity to $2 \mathrm{~m} / \mathrm{s}$ ), at (00:00 pm, 02:00 pm, 04:00 pm, 06:00 $\mathrm{pm}$, 08:00 pm, 09:00 pm). For visualisation of study areas in infrared spectre there were applied the measurments using by Thermo Pro TM TP 8 - IR Thermal Camera.

Map 1: Location of Cultural Center Hidepark - locality with study areas
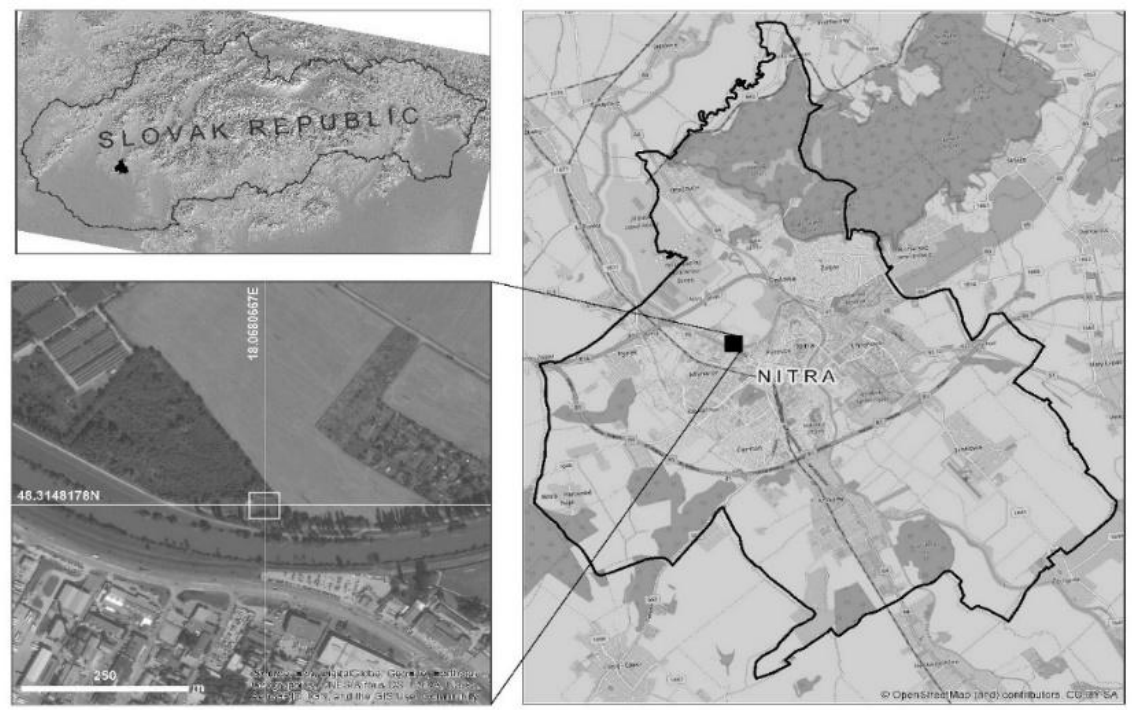

Microclimatic data were statistically evaluated in software Statistica 8 by using the Anova one way (Analysis of variance), Friedman Anova and Tukey HSD test. On the base of statistical evaluation and visualisation of thermal images we proposed optimal managment of green spaces with respect to the performance of microclimate features. 


\section{Results}

In the results we analysed data in the border's times $(00: 00 \mathrm{pm}, 06: 00 \mathrm{pm}$, 09:00 pm). Average values of airflow in the locality with study areas ranged in value $(0.2 \mathrm{l} / \mathrm{s})$. In the Table 1 below there are the average values of air temperature in height $20 \mathrm{~cm}$ above the surface of study areas $1-5$ at 00:00 pm. The lowest average value was recorded in the study area $1\left(30.97{ }^{\circ} \mathrm{C}\right)$. Heterogeneous soils have different thermal capacity and conductivity. According to Tužinský (2002) on surface sand and peat overheats and cools down the most, which means that such types of surfaces have the negative thermal capacity and conductivity.

Difference between study area 2 and 1 was $\left(1.47^{\circ} \mathrm{C}\right)$. In the study areas 3 and 4 was the average value of air temperature aligned, with difference $\left(0.1^{\circ} \mathrm{C}\right)$. The highest average value of air temperature was recorded in the study area 5 $\left(34.77{ }^{\circ} \mathrm{C}\right)$. That refers to overheating of assimilation organs. In relative air humidity (Table 2) were recorded statistically significant differences between study areas $1-3(\mathrm{p}=0.03 ; \mathrm{p}<0,05)$, study areas $1-5(\mathrm{p}=0.0347 ; \mathrm{p}<0,05)$. The lowest average value was recorded at 00:00 pm in the study area $3(29.42 \%)$, reversely the highest value was recorded in the study area $1(37.14 \%)$.

Table 1: Average value of air temperature $\left({ }^{\circ} \mathrm{C}\right)$ in the height $20 \mathrm{~cm}$ over the surface at 00:00 pm

\begin{tabular}{|cccccc|}
\hline $\begin{array}{c}\text { Air } \\
\text { area 1 }\end{array}$ & $\begin{array}{c}\text { Study } \\
\text { area 2 }\end{array}$ & $\begin{array}{c}\text { Study } \\
\text { area 3 }\end{array}$ & $\begin{array}{c}\text { Study } \\
\text { area 4 }\end{array}$ & $\begin{array}{c}\text { Study } \\
\text { area 5 }\end{array}$ \\
temperature & 30.97 & 32.44 & 33.48 & 33.38 & 34.77 \\
Study area 1 & & & $* 0.00027$ & $* 0.00037$ & $* 0.00011$ \\
Study area 2 & & & & & $* 0.00039$ \\
Study area 3 & & & & & \\
Study area 4 & & & & & \\
Study area 5 & & & & & \\
\hline
\end{tabular}

*statistically differences

Wet and dry type of humidity's vertical gradient is revealed in the distribution of air humidity in the ground microclimatic layer of soil. Study area 1 showed the wet type, when the capacity of water vapour and relative humidity above the soil's surface were higher values.

The highest overheating of surface at 00:00 pm was recorded in the study area 2 (Table 3 ). In the study area 3 was mean value of surface temperature (45.85 ${ }^{\circ} \mathrm{C}$ ), in the study area 4 was recorded at $00: 00 \mathrm{pm}-48.55{ }^{\circ} \mathrm{C}$, difference was 2.7 ${ }^{\circ} \mathrm{C}$. It is pointing to the effect of overheating areas with grass biomass exposed to direct solar radiation in time of possitive energe balance. Over the active surface runs constant energy balance. In daily hours, when receiving of solar radiation 
exceeds thermal loss, surface temperature is rising. At 6:00 pm mean values of air temperature $20 \mathrm{~cm}$ over study areas were recorded $25.47{ }^{\circ} \mathrm{C}-$ study area 5 , to $26.09{ }^{\circ} \mathrm{C}$ - study area 1 . Minimal difference was achieved between study areas $\left(0.62{ }^{\circ} \mathrm{C}\right)$ in the time of negative energy balance. In the study area 5 in time of negative energy balance we recorded the highest relative air humidity compared to other study areas - at the lowest air temperature and the lowest surface temperature. The thin air's layer closely with active surface follows ,equivalent relative air humidity“. In this layer temperature and humidity conditions differ from surrounding atmosphere by the influence of radiation and evaporation processes. There is an assumption that by higher temperature of active surface than the air temperature over the active surface, the equivalent relative air humidity is lower than the measuring relative air humidity (Špánik, Šiška et al., 2004). The selected microclimatic factors and thermal images were evaluated separately for representative measuring's day (11.07.2016). In the Graph 1 we introduce daily amplitude of air temperature in the locality with study areas compared to amplitude of air temperature $20 \mathrm{~cm}$ over the surface of study areas 1-5. At 0:00 pm air temperature in the locality with study areas was recorded $-26.9{ }^{\circ} \mathrm{C}$ with differences study area $1\left(0.54{ }^{\circ} \mathrm{C}\right)$, study area $2\left(1.81^{\circ} \mathrm{C}\right)$, study area $3\left(2.51^{\circ} \mathrm{C}\right)$, study area $4\left(2.76^{\circ} \mathrm{C}\right)$, study area $5\left(4.0^{\circ} \mathrm{C}\right)$. Figure 1 shows the increase of air temperature in the locality with study areas in time interval 0:00 pm $-4: 00 \mathrm{pm}$. Slight decrease of total air temperature $\left(1.4{ }^{\circ} \mathrm{C}\right)$ was recorded between 4:00 pm 6:00 pm. Significant decrease of air temperaure over the study area 5 was documented between 6:00 pm $-8: 00 \mathrm{pm}$, at 9:00 pm is the air temperature the lowest comparing to the air temperature in the locality with study areas $\left(2.82{ }^{\circ} \mathrm{C}\right)$. On the contrary difference in air temperature between study area 1 and locality with study areas was recorded $-0.5^{\circ} \mathrm{C}$ ). Daily amplitude of relative air humidity in the locality with study areas and $20 \mathrm{~cm}$ over the surface of study areas $1-5$ is presented in Graph 2.

Table 2: Average value of relative air humidty (\%) in the height of $20 \mathrm{~cm}$ over the surface at 00:00 pm

\begin{tabular}{|cccccc|}
\hline & $\begin{array}{c}\text { Study } \\
\text { area 1 }\end{array}$ & $\begin{array}{c}\text { Study } \\
\text { area 2 }\end{array}$ & $\begin{array}{c}\text { Study } \\
\text { area 3 }\end{array}$ & $\begin{array}{c}\text { Study } \\
\text { area 4 }\end{array}$ & $\begin{array}{c}\text { Study } \\
\text { area 5 }\end{array}$ \\
$\begin{array}{c}\text { Relative air } \\
\text { humidity }\end{array}$ & 37.14 & 31.21 & 29.42 & 30.47 & 29.64 \\
Study area 1 & & & $* 0.0300$ & & $* 0.0347$ \\
Study area 2 & & & & & \\
Study area 3 & & & & & \\
Study area 4 & & & & & \\
Study area 5 & & & & & \\
\hline
\end{tabular}

*statistically differences 
Table 3: Surface temperature $\left({ }^{\circ} \mathrm{C}\right)$ in the study areas 1-5

\begin{tabular}{|cccccc|}
\hline Surface & Study area & Study area & Study area & Study area & $\begin{array}{c}\text { Study } \\
\text { temperature }\end{array}$ \\
$\mathbf{1}$ & $\mathbf{2}$ & $\mathbf{3}$ & $\mathbf{4}$ & area 5 \\
$\mathbf{0 0 : 0 0} \mathbf{~ p m}$ & 51.8 & 53.2 & 42.4 & 50.2 & 29.8 \\
$\mathbf{0 2 : 0 0} \mathbf{~ p m}$ & 50.2 & 51.6 & 52.7 & 51.7 & 36.1 \\
$\mathbf{0 4 : 0 0} \mathbf{~ p m}$ & 49.1 & 50.8 & 44.6 & 45.8 & 33.5 \\
$\mathbf{0 6 : 0 0} \mathbf{~ p m}$ & 30.1 & 29.8 & 30.3 & 28.8 & 24.7 \\
$\mathbf{0 8 : 0 0} \mathbf{~ p m}$ & 24.9 & 23.6 & 24.00 & 23.6 & 18.7 \\
$\mathbf{0 9 : 0 0} \mathbf{~ p m}$ & 14.7 & 13.1 & 13.1 & 12.5 & 9.7 \\
\hline
\end{tabular}

Relative air humidity in the locality with study areas was recorded in range $(25.5 \%$ - 2:00 pm - 54.5\% - 9:00 pm) with difference: study area $1(+3.9 \%)$, study area $(-0.75 \%)$, study area $3(-0.92 \%)$, study area $4(-3.76 \%)$, study area 5 $(-2.14 \%)$. Increase of relative air humidity over the study areas 1-5 was noted between 4:00 pm - 6:00 pm. At 6:00 pm the values of air humidity in particular study areas were higher than values of total relative air humidity in the locality.

At 9:00 pm is relative air humidity $54.5 \%$ in locality with study areas with differences: study area $1(+2.07 \%)$, study area $2(+5.1 \%)$, study area $3(+6.05 \%)$, study area $4(+8.94 \%)$, study area $5(+11.34 \%)$. Daily amplitude of surface temperature in the study areas 1-5 in relation to daily amplitude of surface temperature in the locality with study areas at 0:00 pm-2:00 pm-4:00 pm-6.00 pm8:00 pm-9:00 pm is presented in Graph 3. The lowest values of surface temperature were recorded in the study area 5 with mowing in the height of 15 $20 \mathrm{~cm}$. Increase of surface temperature $\left(6.3{ }^{\circ} \mathrm{C}\right)$, in the study area $3\left(10.3{ }^{\circ} \mathrm{C}\right)$ was recorded in time of possitive energy balance $(0: 00 \mathrm{pm}-2: 00 \mathrm{pm})$.

Daily amplitude of surface temperature in the study area 5 was in range $(9.7$ $\left.{ }^{\circ} \mathrm{C}-9: 00 \mathrm{pm}-36.1{ }^{\circ} \mathrm{C}-2: 00 \mathrm{pm}\right)$ - value of daily amplitude study area $5\left(26.4{ }^{\circ} \mathrm{C}\right)$, study area $4\left(39.2^{\circ} \mathrm{C}\right)$, study area $3\left(39.6^{\circ} \mathrm{C}\right)$, study area $2\left(40.1^{\circ} \mathrm{C}\right)$, study area 1 $\left(37.1^{\circ} \mathrm{C}\right)$.

Graph 1: Daily amplitude of air temperature in the height of $20 \mathrm{~cm}$ over the surface in the study areas $1-5$ in relation to air temperature

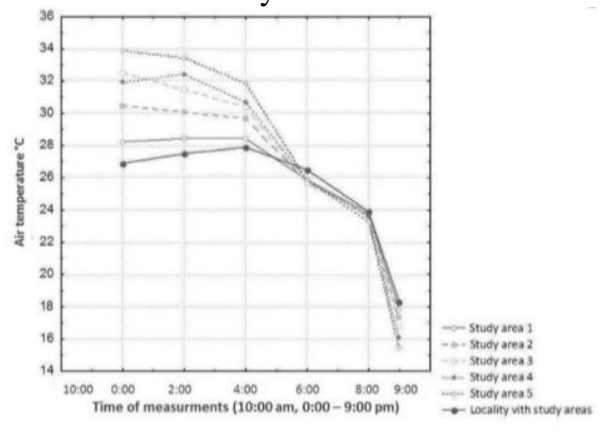


Graph 2: Daily amplitude of relative air humidity in the height of $20 \mathrm{~cm}$ over the surface in the study areas 1-5 in relation to relative air humidity

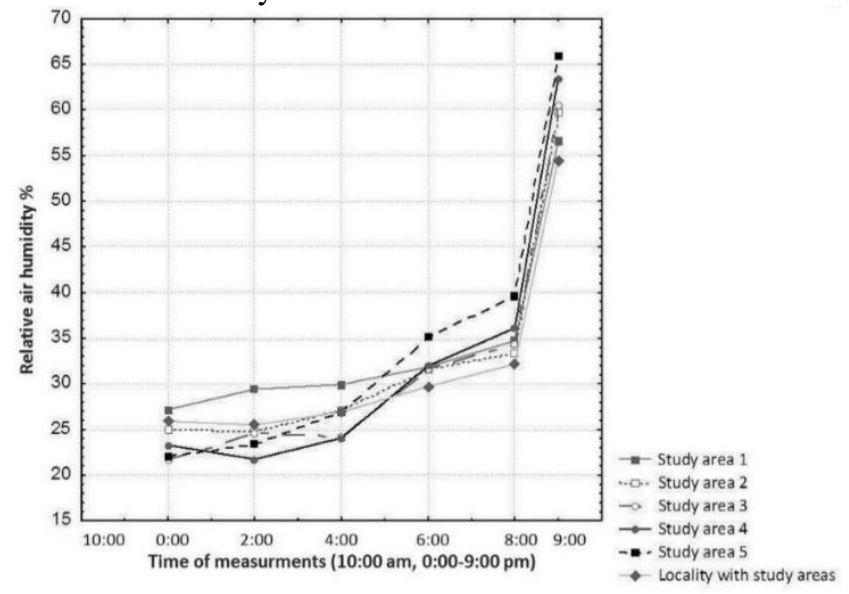

Graph 3: Daily amplitude of surface temperature in the study areas $1-5$ in relation to daily amplitude of air temperature in the locality with study areas

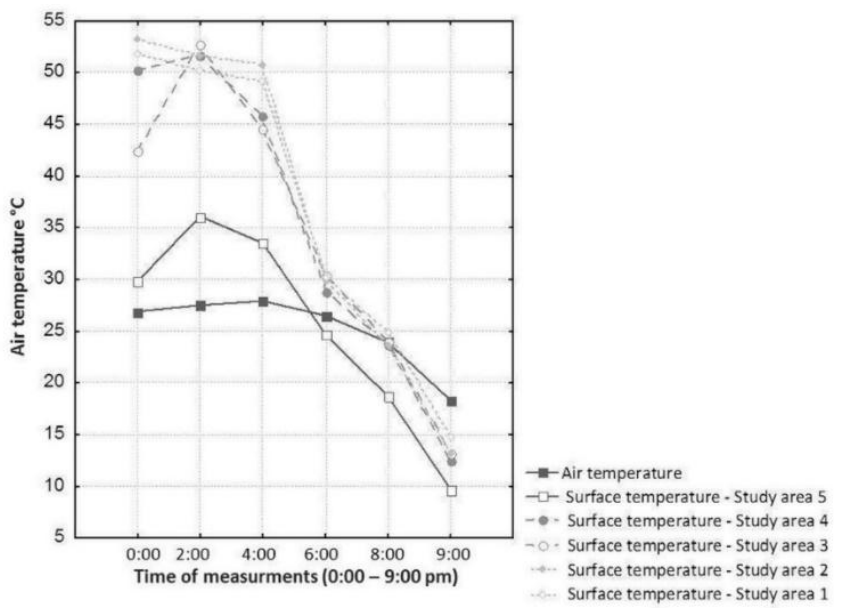

Decrease of surface temperature is significant in the study area 5 under the value of air temperature in the locality with study areas (between 4:00 - 6:00 pm). In the study areas 1-4 decrease of surface temperature occurs much later - between 8:00 - 9:00 pm). Daily amplitude of air temperature and relative air humidity in the locality with study areas is shown in Table 4 . Table 4 implies maximum value of air temperature at 4:00 $\mathrm{pm}\left(27.9^{\circ} \mathrm{C}\right)$ and minimum value at 9:00 $\mathrm{pm}\left(18.3^{\circ} \mathrm{C}\right)$. 
Table 5 belows the value of air temperature in height $20 \mathrm{~cm}$ over the surface of study areas $1-5$. The air temperature in range $\left(28.44^{\circ} \mathrm{C}-\right.$ at $4: 00 \mathrm{pm}-$ maximum) to $\left(17.80{ }^{\circ} \mathrm{C}\right.$ - at 9:00 pm - minimum) was recorded in the study area 1 . Minimum value at 9:00 $\mathrm{pm}-17.33{ }^{\circ} \mathrm{C}$, maximum value at $0: 00 \mathrm{pm}-30.50{ }^{\circ} \mathrm{C}$, with difference $13.17{ }^{\circ} \mathrm{C}$ was recorded in the study area 2 (complete mowing with uncovering of soil and retained of grass biomass).

Table 4: Average value of air temperature $\left({ }^{\circ} \mathrm{C}\right)$ and relative air humidity $(\%)$ in the locality with study areas in selected times of measurments

\begin{tabular}{|ccc|}
\hline Time of measurment & Air temperature $\left({ }^{\circ} \mathbf{C}\right)$ & Relative air humidity (\%) \\
$\mathbf{0 0 : 0 0} \mathbf{~ p m}$ & 26.9 & 25.9 \\
$\mathbf{0 2 : 0 0} \mathbf{~ p m}$ & 27.5 & 25.5 \\
$\mathbf{0 4 : 0 0} \mathbf{~ p m}$ & 27.9 & 26.9 \\
$\mathbf{0 6 : 0 0} \mathbf{~ p m}$ & 26.5 & 29.7 \\
$\mathbf{0 8 : 0 0} \mathbf{~ p m}$ & 23.9 & 32.2 \\
$\mathbf{0 9 : 0 0} \mathbf{~ p m}$ & 18.3 & 54.5 \\
\hline
\end{tabular}

Maximum value of air temperature at 0:00 $\mathrm{pm}-32.52{ }^{\circ} \mathrm{C}$, minimum value at $9: 00 \mathrm{pm}-16.79^{\circ} \mathrm{C}$, with difference $15.73{ }^{\circ} \mathrm{C}$ was recorded in the study area 3 with mowing in the height of $10 \mathrm{~cm}$. In the study area 4 with mowing in the height of $10 \mathrm{~cm}$ and retained of grass biomass, were the mean values of air temperature in range (minimum $-16.10{ }^{\circ} \mathrm{C}$, maximum $-32.45^{\circ} \mathrm{C}$ at 2:00 pm), difference was $16.35{ }^{\circ} \mathrm{C}$. In the study area 5 with mowing in the height of $15-20 \mathrm{~cm}$, was recorded the lowest value of air temperature over the surface at 9:00 $-15.48{ }^{\circ} \mathrm{C}$, the highest value was recorded at $0: 00 \mathrm{pm}-33.88^{\circ} \mathrm{C}$, with difference $18.4{ }^{\circ} \mathrm{C}$ in daily amplitude. The highest difference in air temperature over the surface of study areas was recorded between study areas $1-5\left(7.76{ }^{\circ} \mathrm{C}\right)$ in daily amplitude. Table 6 implies the daily amplitude of relative air humidity in the height $20 \mathrm{~cm}$ over the surface of study areas 1-5. Maximum values were recorded at 9:00 pm. The lowest value was recorded in the study area $1(56.57 \%)$, the highest value in the study area $5(65.84 \%)$ with difference $9.27 \%$.

Table 5: Air temperature $\left({ }^{\circ} \mathrm{C}\right)$ in the height of $20 \mathrm{~cm}$ over the surface in the study areas 1-5

\begin{tabular}{|cccccc|}
\hline $\begin{array}{c}\text { Air } \\
\text { temperature }\end{array}$ & $\begin{array}{c}\text { Study } \\
\text { area 1 }\end{array}$ & $\begin{array}{c}\text { Study } \\
\text { area 2 }\end{array}$ & $\begin{array}{c}\text { Study } \\
\text { area 3 }\end{array}$ & $\begin{array}{c}\text { Study } \\
\text { area 4 }\end{array}$ & $\begin{array}{c}\text { Study } \\
\text { area 5 }\end{array}$ \\
$\mathbf{0 0 : 0 0 ~}$ pm & 28.24 & 30.50 & 32.52 & 31.96 & 33.88 \\
$\mathbf{0 2 : 0 0 ~} \mathbf{~ p m}$ & 28.43 & 30.07 & 31.47 & 32.45 & 33.43 \\
$\mathbf{0 4 : 0 0 ~} \mathbf{~ p m}$ & 28.44 & 29.71 & 30.41 & 30.66 & 31.90 \\
$\mathbf{0 6 : 0 0} \mathbf{~ p m}$ & 25.87 & 25.74 & 25.71 & 25.83 & 25.90 \\
$\mathbf{0 8 : 0 0} \mathbf{~ p m}$ & 23.80 & 23.70 & 23.75 & 23.60 & 23.30 \\
$\mathbf{0 9 : 0 0} \mathbf{~ p m}$ & 17.80 & 17.33 & 16.79 & 16.10 & 15.48 \\
\hline
\end{tabular}


Table 6: Relative air humidity (\%) in the height of $20 \mathrm{~cm}$ over the surface in the study areas $1-5$

\begin{tabular}{|cccccc|}
\hline $\begin{array}{c}\text { Relative air } \\
\text { humidity }\end{array}$ & $\begin{array}{c}\text { Study } \\
\text { area 1 }\end{array}$ & $\begin{array}{c}\text { Study } \\
\text { area 2 }\end{array}$ & $\begin{array}{c}\text { Study } \\
\text { area 3 }\end{array}$ & $\begin{array}{c}\text { Study } \\
\text { area 4 }\end{array}$ & $\begin{array}{c}\text { Study } \\
\text { area 5 }\end{array}$ \\
$\mathbf{0 0 : 0 0 ~ p m}$ & 27.16 & 25.04 & 21.70 & 23.28 & 22.01 \\
$\mathbf{0 2 : 0 0}$ pm & 29.40 & 24.75 & 24.58 & 21.74 & 23.36 \\
$\mathbf{0 4 : 0 0}$ pm & 29.92 & 27.17 & 24.12 & 24.06 & 26.83 \\
$\mathbf{0 6 : 0 0}$ pm & 31.84 & 31.64 & 31.50 & 31.94 & 35.19 \\
$\mathbf{0 8 : 0 0}$ pm & 34.70 & 33.30 & 34.25 & 36.10 & 39.50 \\
$\mathbf{0 9 : 0 0} \mathbf{~ p m}$ & 56.57 & 59.60 & 60.55 & 63.44 & 65.84 \\
\hline
\end{tabular}

\section{Discussion}

Vysoudil et al. (2012) were dealing with evaluation of the mode of surface temperature on the base of surface thermal monitoring in Olomouc (Czech Republic). Using the thermal camera for detection of surface temperature is unique method in climatology. However it is operative method by deriving of thermal regime of ground atmosphere's layer in urban environment. Exact description of surface temperature involves the realization of thermal images in days with dominant radiation mode. The impact of management of green spaces on overheating of active surface was evaluated on experimental basis in this study. Except for measuring by using the Anemometer TSI Veloci Calc and Infrared thermometer, we used the Thermal camera Thermo Pro TM TP 8 (Figure 1). Continuously capturing and visualization of study areas in infrared spectre is considered as very effective method. Analysis of thermal images and statistical evaluation of microclimatic factors bring detail information about daily amplitude of surface temperature in relation to implement management measures. It is also possible to visually interpret and compare the ability to accumulate solar radiation in the study areas 1-5. Vysoudil et al., (2012) analyzed the surface temperature of vegetation in the border of Olomouc. From results of their study implies the significant difference between anthropogenic surface's temperature $\left(37.4{ }^{\circ} \mathrm{C}\right)$ and vegetation's surface temperature $\left(29.8^{\circ} \mathrm{C}\right)$. From results of our study follows daily values of surface temperature $(0: 00-6: 00 \mathrm{pm})$, study area 1 (complete mowing with uncovering of soil) $-45.3{ }^{\circ} \mathrm{C}$, study area 2 (complete mowing with uncovering of soil and retained of grass biomass) $-46.3{ }^{\circ} \mathrm{C}$, study area 3 with mowing in the height of $10 \mathrm{~cm}\left(42.5^{\circ} \mathrm{C}\right)$, study area 4 with mowing in the height of $10 \mathrm{~cm}$ and retained of grass biomass $\left(44.1^{\circ} \mathrm{C}\right)$, study area 5 with mowing in the height of $15-20 \mathrm{~cm}\left(31{ }^{\circ} \mathrm{C}\right)$. According to (Leuzinger, Körner, Voogt, 2010) trees are essential in a dense urban environment not only because of their aesthetic value, but also for their cooling effect during hot periods, which impacts directly the local microclimate. The significant factor is adequate management of green spaces in relation to microclimatic conditions in urban environment as our study 
points on. Thermal infrared (TIR) remote sensing techniques have been applied in urban climate and environmental studies, mainly for analyzing land surface temperature (LST) patterns and its relationship with surface characteristics, assessing urban heat island (UHI), and relating LSTs with surface energy fluxes to characterize landscape properties, patterns, and processes (Weng, 2009). Microclimatic function of vegetation is the ability of vegetation by transpiration to amend humidity and thermal conditions - cooling effect, decreasing of air flow, insuring overshadow and dampening wind gusts. These factors form thermal comfort of citizens.

Figure 1: Study areas 1-5 in infrared spectre in selected times of measurments
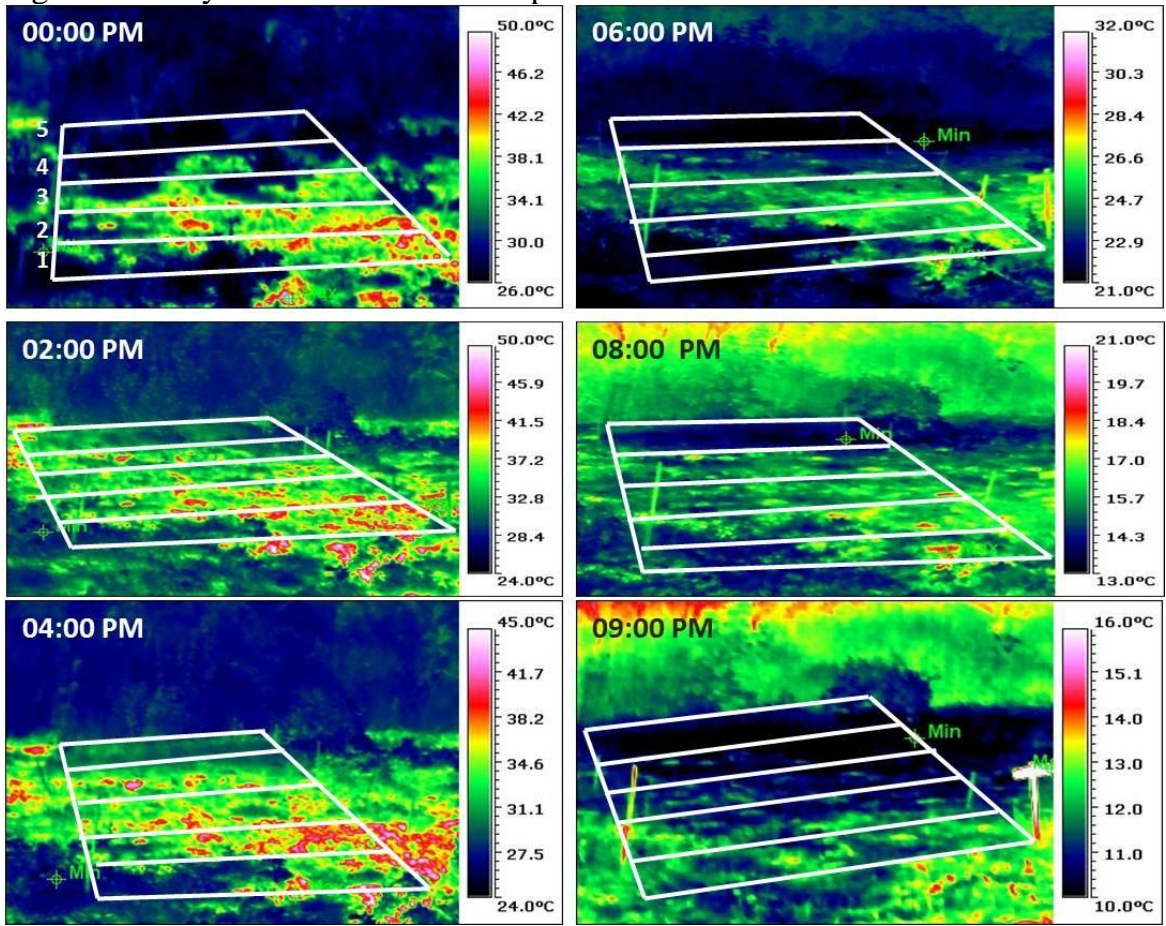

According to Salata, Golasi, Bisegna (2015) this impact is the reason why nowadays there is such focus on strategies for allevation of climate change. However these strategies depend on passive factors, that are characterized by urban environment and are able to influence the values of meteoroligal variables.

Our case study applied in Nitra brings the different view on the microclimatic effect of vegetation in urban environment. Study is focusing on the effect of green spaces-grasslands, which are signifficant active surface 
contributing on the total thermal bilancy. Our results show on the significant differences between microclimatic factors in relation to applied managment. Considering to extremely high temperatures in the summer and to strategically adaptation of cities to this new trend, it would be appropriate to apply the results of similar studies in the managment measures in vegetation areas realized by selfgoverment.

\section{Conclussion}

The active management contributes to favorable thermal balance during the day, it shows in daily amplitude of surface temperature - heating of active surface. Cooling effect and thermoregulation occur in the earlier hours (4:00-6:00 pm) Study area 5 in comparing to study areas with unsuitable management (8:00-9:00 pm) - Study areas 1-4. These areas have higher accumulation of solar radiation and surface temperature - than an anthropogenic surface (for example asphalt, concrete). Overheating under the influence of retained grass biomass has occured during the summer months with the highest average daily temperature. Grass biomass in the study areas 2, 4 showed the highest absorption of solar radiation and resulting change on the thermal energy. In the study area 1 regime of relative air humidity influenced uncovering of soil with absention of ground cover. The highest values of relative air humidity $20 \mathrm{~cm}$ over the surface of study area comparing to other study areas were recorded in time interval $(0: 00-4: 00 \mathrm{pm})$. From the viewpoint of vertical distribution of humidity in the study area 1 we can talk about „wet type“, when the water vapour capacity and relative air humidity narrow the surface showed the highest values. After the evaluation of analysis in the locality with study areas 1-5 we can state, that the optimal management in summer months is the management in the study area 5 with mowing in the height of $15-20 \mathrm{~cm}$ without retained of grass biomass. Provision of natural green space within the broader umbrella of green infrastructure is now a matter of increasing importance to policy makers and decision takers in the land-use planning system (Stubbs, 2008). Due to their amenity and aesthetics, green spaces increase property value. To ensure multifunctional role of urban a green space is achieved, in particular the social and psychological role, certain standards of quantity, quality and distribution within the urban area should be adequately established (Mwendwa,Giliba, 2013). For the effective elimination of active surface's overheating in time of possitive energy balance is possible to aplicate the adequate management of green spaces. According to our study, open grassland also brings benefits and fulfills significant ecosystem functions as long as they have adequate and functional management in relation to a changing climate. Urban thermal environment highly affects the livability and quality of life of residents. It is the key element of urban microclimate, which could be used to investigate urban heat islands and improve thermal comfort in urban area (Tumini et al., 2016). 


\section{Acknowledgement}

This study is the result of the project implementation by the $<$ Research \& Development Operational Program funded by the ERDF $\neq 1>$ under grant „Environmental aspects of the urban environment" [ITMS 26220220110], by the $<$ The Ministry of Education, Science, Research and Sport of the Slovak Republic and Slovak Academy of Sciences $\neq 2>$ under grant VEGA [1/0496/16] and by the project UGA VIII/2/2017 (University Grant Agenture - Constantine The Philosopher University in Nitra).

\section{References}

ARONSON, M. F. J. - LEPCZYK, A. CH. - EVANS, L. K. - GODDARD, M. A. - LERMAN, S. B. - MACLVOR, J. S. - NILON, H. CH. - VARGO, T. 2017. Biodiversity in the City: key challanges for urban green space management. In Frontiers in Ecology and the Environment. vol. 15, no. 4, pp. 189-196.

BELÍKOVÁ, M. - MACKOVOVÁ, M. - KOČÍK, K. 2013. Posúdenie stavu fytodiverzity vybraných travinno-bylinných spoločenstiev $\mathrm{v}$ katastrálnom území Slovenskej L'upče. In Acta Facultatis Ecologiae. vol. 28, pp. 5-14.

GRUNEWALD, K. - XIE, G. - WÜSTEMAN, H. 2017. The Multiple Benefits of Urban Green - Ecosystem Services Assessment. In Towards Green Cities. pp 43-104.

JANIŠOVÁ, J. - JANÁK, M. 2009. Modelové opatrenia pre suché a dealpínske travinno-bylinné spoločenstvá. [online]. [cit. 2018-08-13]. Available at: drupal.daphne.sk/sites/daphne.sk/files/uploads/MM02_suche_dealpinske_1.pdf

KABISCH, N. - KORN, H. - STADLER, J. - BONN, A. 2017. Nature-Based Solutions to Climate Change Adaptation in Urban Areas. In Kabisch, N., Bosch, M., A. (eds.). Urban Green Spaces and the Potential for Health Improvement and Environmental Justice in a Changing Climate. Cham: Springer. ISBN 978-3-319-56091-5.

KOC, B. C. - OSMOND, P. - PETER, A. 2018. Evaluating of cooling effects of green infrastructure : A systematic review of methods, indicators, and data sources. In Solar Energy. vol. 166, pp. 486-508.

LEUZINGER, S. - VOGT, R. - KÖRNER, CH. 2010. Tree surface temperature in an urban environment. In Agricultural and Forest Meteorology. ISSN 01681923, 2010, vol. 150, pp. 56-62.

MWENDWA, P. - GILIBA, R. A. 2012. Benefits and Challenges of Urban Green Spaces. In Chinese Journal of Population Resources and Environment. vol. 10, no. 1, pp. 73-79.

OKE, T. R. 2006. Initial guidance to obtain representative meteorological observations at urban sites. Instruments and observing methods. Report No. 1. WMO, $47 \mathrm{p}$. 
PATASSINI, D. 2017. Beyond Benefit Cost Anylysis. Accounting for Non-Market Values in Planning Evaluation. In Baycan, T., Nijkamp, P. (eds.) Evaluation of Urban Green Spaces. [online] Chapter 5, p. 25. London: Routledge. ISBN 9781351162678, 340 p. [cit. 2018-09-20]. Available at: <https://www.taylorfrancis.com/books/e/9781351162678>

PLANTUREUX, S. - PEETERS, A. - MCCRACKEN, D. 2005. Biodiversity in intensive grasslands: Effect of management, improvement and challenges. In Agronomy Research. vol. 3, no. 2, pp. 153-164.

RUŽIČKOVÁ, H. - ŠKODOVÁ, I. - JANÁK, M. 2009. Manažmentový model pre mezofilné lúky. [online]. [cit. 2018-09-20]. <www.daphne.sk/sites/ daphne.sk/uploads/MM07_Arrhenatherion_1.pdf/2016/3/6/>

SALATA, F. - GOLASI, I. - VOLLARO, E. - BISEGNA, F. - NARDECHIA, F. - COPPI, M. - GUGLIERMETTI, F. - VOLLARO, A. 2015. Evaluation of different urban microclimate mitigation strategies through a PMV Analysis. In Sustainability. ISSN 2071-1050, 2015, vol. 7, pp. 9012-9030.

SCUDO, M. - DESI, V. - ROGORA, A. 2002. Evaluation of radiant conditions in urban spaces. In Designing open spaces in the urban environment: a bioclimatic approach. pp. 12-17. ISBN 960-86907-2-2.

SHASHUA-BAR, L. - HOFFMAN, M. E. 2000. Vegetation as a climatic component in the design of an urban street. An empirical model for predicting the cooling effect of urban green areas with trees. In Energy and Buildings. vol. 31, no. 3, pp. 221-235.

ŠIŠKA, B. - ŠPÁNIK, F. - REPA, Š. - GÁLIK, M. 2002. Praktická biometeorológia. Nitra: SPU, 2002. 102 p. ISBN 80-8069-047-2.

ŠPÁNIK, F. - ŠIŠKKA, B. - ANTAL, J. - TOMLAIN, J. - ŠKVARENINA, J. REPA, Š. 2004. Biometeorológia. Nitra: SPU, 2004. 227 p. ISBN 80-8069315-3.

STŘEDOVÁ, H. - BOKWA, A. - DOBROVOLNÝ, P. - KRÉDL, Z. KRAHULA, L. - LITSCHMAN, T. - POKORNÝ, R. - ROŽNOVSKÝ, J. STŘEDA, T. - VYSOUDIL, M. 2011. Mikroklima a mezoklima měst, mikroklima porosti̊. Praha: ČHMU, 2011. 102 p. ISBN 978-80-86690-90-2.

STUBBS, M. 2008. Natural green space and planning Policy: Devising a Model for its delivery in Regional Spatial Strategies. In Landscape Research. vol. 33, no. 1, pp. 119-139.

TUMINI, I. - GARCIA, E. H. - RADA, S.B. 2016. Urban microclimate and thermal comfort modelling: strategies for urban renovation. In International Journal of Sustainable Building Technology and Urban Development. vol. 7, no. 1, pp. 22-37.

TUŽINSKÝ, L. 2002. Bioklimatológia. Zvolen: Technická Univerzita vo Zvolene, 2002. 140 p. ISBN 80-228-1150-5.

VOOGT, J. A. - OKE, T. R. 2003. Thermal remote sensing of urban climates. In Remote Sensing of Environment. vol. 86, no. 3, pp. 370-384. 
VYSOUDIL, M. - FRAJER, J. - GELETIČ, J. - LEHNERT, M. - LIPINA, P. PAVELKOVÁ-CHMELOVÁ, R. - ŘEPKA, M. 2012. Podnebí Olomouce. Olomouc: Univerzita Palackého v Olomouci, 2012. 212 p. ISBN 978-80-2443285-4.

WARDOYO, J. et al. 2011. Vegetation Configuration as Microclimate Control Strategy in Hot Humid Tropic Urban Open Space. In SENVAR + ISESEE. 1-3 December 2008, International Seminar in Sustainable Environment \& Architecture.

WENG, Q. 2009. Thermal infrared remote sensing for urban climate and environmental studies: Methods, applications, and trends. In ISPRS Journal of Photogrammetry and Remote Sensing. vol. 64, pp. 335-344.

\section{Mgr. Katarína Veselovská, PhD.}

Department of Ecology and Environmental Sciences

Faculty of Natural Sciences

Constantine the Philospher University in Nitra

Trieda A. Hlinku 1, 94974 Nitra

E-mail: kveselovska@ukf.sk

\section{Mgr. Gabriel Bugár, PhD.}

Department of Ecology and Environmental Sciences

Faculty of Natural Sciences

Constantine the Philospher University in Nitra

Trieda A. Hlinku 1, 94974 Nitra

E-mail: gbugar@ukf.sk 